\title{
A homologue to the Escherichia coli alkyl hydroperoxide reductase AhpC is induced by osmotic upshock in Staphylococcus aureus
}

\author{
Lindsay Armstrong-Buisseret, ${ }^{1}$ Martin B. Cole ${ }^{2}$ and \\ Gordon S. A. B. Stewart ${ }^{1}$
}

Author for correspondence: Gordon S. A. B. Stewart. Tel: 0115 9516165. Fax: 01159516162.

e-mail: SCZGSS@SZN1.agric.nott.ac.uk

\author{
1 Department of Applied \\ Biochemistry and Food \\ Science, University of \\ Nottingham, Faculty of \\ Agricultural and Food \\ Sciences, Sutton Bonington \\ Campus, Leicestershire \\ LE12 5RD, UK \\ 2 Unilever Research, \\ Colworth Laboratory, \\ Colworth House, \\ Sharnbrook, Bedfordshire \\ MK44 1LQ, UK
}

\begin{abstract}
Four major proteins are induced in Staphylococcus aureus in response to hyperosmotic shock caused by the presence of two different osmolytes, sucrose and $\mathrm{NaCl}$. The gene encoding one of these proteins was isolated using a novel PCR procedure. The derived protein sequence shows extensive similarity to a subunit of alkyl hydroperoxide reductase (AhpC) from both Escherichia coli and Salmonella typhimurium. Exposure of S. aureus to varying concentrations of $\mathrm{H}_{2} \mathrm{O}_{2}$ did not result in the detectable induction of AhpC.
\end{abstract}

Keywords: Stapbylococcus aureus, alkyl hydroperoxide reductase, osmotic stress, oxidative stress

\section{INTRODUCTION}

Stapbylococcus aureus is a pathogen that can cause a wide variety of diseases ranging from superficial cutaneous infections (Noble \& White, 1983) to life-threatening systemic diseases (Wheat et al., 1983; Parker, 1984). Certain strains of $S$. aureus are also the causative agents of staphylococcal food poisoning (Bergdoll, 1983; Troller, 1986; Johnson et al., 1991).

S. aureus has an unusual characteristic among nonhalophilic bacteria in that it has a very low minimum water activity $\left(a_{\mathrm{w}}\right)$ for growth of 0.86 (Scott, 1953). Integral with the above is the ability of $S$. aureus to tolerate and grow in media or food products containing a high concentration of $\mathrm{NaCl}$ (Jay, 1992).

Following extensive studies of osmoregulation in enteric bacteria, there have recently been significant strides in elucidating the physiology of osmoregulation in $S$. aureus (Miller et al., 1991; Graham \& Wilkinson, 1992; Townsend \& Wilkinson, 1992; Bae \& Miller, 1992; Bae et al., 1993; Kaenjak et al., 1993; Pourkomailian \& Booth, 1993). The initial effect of osmotic upshock in enterics is the accumulation of $\mathrm{K}^{+}$induced by a decrease in turgor pressure. S. aureus, however, naturally contains high levels of cytoplasmic $\mathrm{K}^{+}$and glutamate (Kunin \& Rudy, 1991;

The EMBL accession number for the nucleotide sequence data reported in this paper is $X 85029$.
Graham \& Wilkinson, 1992), implying that in the event of an osmotic upshock it accumulates some other form of compatible solute. Townsend \& Wilkinson (1992) and Bae \& Miller (1992) have described the existence of two $\mathrm{Na}^{+}$-dependent proline transport systems in $S$. aureus; a high-affinity system involved in scavenging low concentrations of exogenous proline, and a low-affinity system involved in osmoregulation. Neither system requires induction by proline or by hyperosmotic shock and new protein synthesis is not required for the transport of proline. Hence it seems that osmotic upshock activates a pre-existing system that transports exogenous proline into the cell to act as a compatible solute. The proline transport system and the associated glycine betaine transport systems (Pourkomailian \& Booth, 1993) are not therefore candidates for gene induction. The osmoprotective nature of choline with respect to $S$. aureus was first demonstrated by Graham \& Wilkinson (1992). Kaenjak et al. (1993) detailed how choline uptake in $S$. aureus, initiated by osmotic stress, occurred via an inducible transport system. Choline utilization is, therefore, one example of the necessity for de novo protein synthesis, and hence gene expression, following osmotic shock. However, to date the induction of genetic systems in terms of osmoregulation in $S$. aureus has not been elucidated.

The present paper initiates such studies and demonstrates that under extreme osmotic stress, caused by two different osmolytes, $S$. aureus induces the expression of a number of novel proteins. One of these proteins is a homologue of 
the Escherichia coli AhpC component of an alkyl hydroperoxide reductase.

\section{METHODS}

Bacterial strains and plasmids. The bacterial strains and plasmids used were: Stapbylococcus aureus RN4220 (derivative of NCTC 8325 cured of prophages) (Kreiswirth et al., 1983); Escherichia coli JM109 $\{\Delta($ lac-pro $A B) \operatorname{rec} A 1$ end $A 1$ gyr $A 9 b$ thi bsdR17 supE44 relA1 $\mathrm{F}^{\prime}\left[\operatorname{traD} 36\right.$ pro $A B$ lac ${ }^{q}$ lacZ $\left.\left.\Delta \mathrm{M} 15\right]\right\}$ (Yanisch-Perron et al., 1985); Bacillus subtilis NCTC 3610; S. epidermidis NCTC 11047; Salmonella typhimurium NCTC 74; Listeria monocytogenes NCTC 4885; Campylobacter jejuni NCTC 11351; pUC19 Ap ${ }^{\mathbf{R}}$, multicloning site within lacZ (YanischPerron et al., 1985). Cultures were grown aerobically at $37^{\circ} \mathrm{C}$, liquid cultures were shaken at 200 r.p.m. Unless otherwise stated, liquid cultures were grown in LB medium (Sambrook et al., 1989) and plated cultures were on LB solidified with $15 \mathrm{~g}$ agar $\mathrm{l}^{-1}$ (LA). Strains were maintained on LA plates stored at $4{ }^{\circ} \mathrm{C}$ and were also kept as $10 \%(\mathrm{v} / \mathrm{v})$ glycerol $/ 90 \%(\mathrm{v} / \mathrm{v}) \mathrm{BHI}$ stocks at $-20^{\circ} \mathrm{C}$. Ampicillin (Ap, $50 \mathrm{mg} \mathrm{l}^{-1}$ ), IPTG (40 $\mathrm{mg} \mathrm{l}^{-1}$ ) and $\mathrm{X}$-gal (40 $\mathrm{mg} \mathrm{l}^{-1}$ ) (Sigma) were used as required.

Preparation of total cell protein profiles. An adaptation of the method described by Johnstone et al. (1982) was used as follows: cultures of $S$. aureus were grown to mid-exponential phase $\left(\mathrm{OD}_{600}\right)$ and $10 \mathrm{ml}$ portions were centrifuged in an MSE Centaur 2 at $2100 \mathrm{~g}$ for $15 \mathrm{~min}$. The supernatant was removed and the cell pellet resuspended in $0.7 \mathrm{ml}$ ice-cold PEP buffer [1 mM PMSF (Sigma), $30 \mathrm{mM}$ EDTA (Fisons) made up to volume with PBS (Oxoid)]. The suspension was removed into a glass test tube containing $4 \cdot 1-4 \cdot 2$ g glass beads (106 $\mu \mathrm{m}$, Sigma) which was kept on ice. The test tube was vortexed for $1 \mathrm{~min}$ intervals, being returned to ice between each interval, until about $90 \%$ of the cells had lysed (usually 5-10 min, as determined by phase microscopy on a Nikon Optiphot Microscope). Ice-cold PEP buffer $(5 \mathrm{ml})$ was added to the suspension which was subsequently filtered under vacuum using a $0.45 \mu \mathrm{m}$ pore filter (Whatman) to remove the glass beads. The lysed cells suspension was then concentrated using a Centricon-30 device (Amicon, molecular mass cut-off of $30 \mathrm{kDa}$, maximum vol. $2 \mathrm{ml}$ ) or an ultrafiltration unit (Amicon, molecular mass cut-off $30 \mathrm{kDa}$, maximum vol. $50 \mathrm{ml}$ ) depending on the volume of the suspension. The retentate was stored at $-20^{\circ} \mathrm{C}$ until required.

Electroblotting of proteins and $\mathrm{N}$-terminal amino acid sequence analysis. Proteins that were to be subjected to $\mathrm{N}$ terminal amino acid sequence analysis were initially immobilized onto ProBlott PVDF membrane (Applied Biosystems) at $50 \mathrm{~V}$ for $30 \mathrm{~min}$ at room temperature. After blotting, the membrane was removed from the apparatus, washed in sterile distilled water, dried, and kept in a sterile tube at $-20^{\circ} \mathrm{C}$ until required. Proteins immobilized onto ProBlott membranes were subjected to $\mathrm{N}$-terminal amino acid sequence analysis performed by $\mathrm{J}$. Keyte and K. Bailey at the Queens Medical Centre, Nottingham, using an Applied Biosystems 473A automatic sequencer.

Preparation of chromosomal DNA. Chromosomal DNA was prepared according to the method detailed in Ausubel et al. (1990). During preparation of staphylococcal DNA, cell lysis was achieved via the initial addition of $100 \mu \mathrm{l}$ lysostaphin $\left(10 \mathrm{mg} \mathrm{ml}^{-1}\right.$, Sigma) and $100 \mu \mathrm{l}$ lysozyme $\left(10 \mathrm{mg} \mathrm{ml}^{-1}\right.$, Sigma) with incubation at $37^{\circ} \mathrm{C}$ for $1 \mathrm{~h}$. All bacterial strains were subjected to the treatment of $0.5 \mathrm{ml} 10 \%(\mathrm{w} / \mathrm{v})$ SDS and $50 \mu \mathrm{l}$ proteinase $\mathrm{K}\left(20 \mathrm{mg} \mathrm{ml}^{-1}\right.$, Sigma) with incubation at $37^{\circ} \mathrm{C}$ for $1 \mathrm{~h}$. Contaminating proteins and cell wall material were removed by the addition of an equal volume of phenol/chloroform and the DNA was subsequently precipitated by the addition of 0.6 vols 2 -propanol. The $\mathrm{CsCl}$ purification step was omitted.

LAB2 Primer. Amino acid residues 10-16 were chosen from the $\mathrm{N}$-terminal amino acid sequence of Protein 4 as a region that, when reverse-transcribed into DNA, contained the least number of degeneracies; this region, however, still has 1024-fold degeneracy $(2 \times 4 \times 4 \times 2 \times 4 \times 2 \times 2)$. This level of degeneracy is too high for application as an effective gene probe and the primer degeneracy was reduced by applying the G-T pairing rule as described by Iwanejko et al. (1989). By this means the degeneracy of the DNA sequence was reduced to eightfold $(2 \times 2 \times 2)$ as depicted below:

$5^{\prime}$

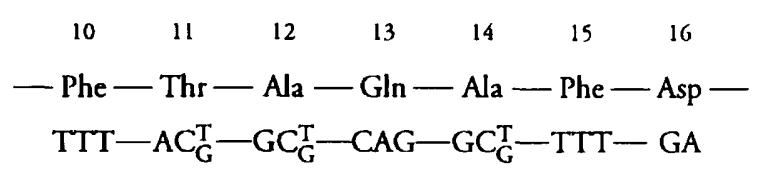

The final primer LAB2 has the additional sequence 5' GGGCCCGGGAATTCAAGCTT3', 5' of Phe codon 10 to provide restriction sites for $S m a I$, EcoRI and HindIII, giving a primer of 40 nucleotides in total.

PCR technique. The concept of a novel PCR cloning technique was based on the fact that amplification of the desired gene product would occur without the use of any chromosomal cloning procedures; the only genomic DNA involved would be that of $S$. aureus and problems of hybridization to E. coli (see Results and Discussion) could be eliminated.

S. aureus chromosomal DNA and pUC19 were digested with EcoRI and ligated together. Within this ligation mixture there will be a particular recombinant containing an insert of $S$. aureus DNA on which will be located the gene of interest and hence the complementary sequence to LAB2. This fragment of $S$. aureus DNA could insert into the vector in either of two orientations, i.e. with $\mathrm{LAB} 2$ facing $\operatorname{lac} Z$ (located in the vector DNA) or with $L A B 2$ pointing away from lac $Z$. The whole ligation reaction was then used as the template in a PCR reaction where the primer pairs were either the M13 reverse primer (M13R) and LAB2, or the universal primer (UP) and LAB2.

PCR amplifications were performed as described by Saiki $e t$ al. (1988) using 1 U Taq DNA polymerase (subsequently renamed Thermostable DNA Polymerase, Advanced Biosystems) per reaction, buffer supplied with the enzyme and $1.5 \mathrm{mM} \mathrm{MgCl}$. About $1 \mu \mathrm{g}$ of each primer per reaction was included and reactions performed in a Techne PHC-3 Thermal Cycler. A typical run involved one cycle of template denaturation at $95{ }^{\circ} \mathrm{C}$ for $2 \mathrm{~min}$, followed by annealing of primers to the template at $50{ }^{\circ} \mathrm{C}$ for $1 \mathrm{~min}$. Immediately after this, there followed 30 cycles of extension of the primer-template complex at $72^{\circ} \mathrm{C}$ for $1 \mathrm{~min}$, denaturation at $95^{\circ} \mathrm{C}$ for $30 \mathrm{~s}$ and annealing at $50^{\circ} \mathrm{C}$ for $30 \mathrm{~s}$. The run finished with an extension at $72^{\circ} \mathrm{C}$ for $5 \mathrm{~min}$ to ensure completion of all strands. The annealing temperature was varied depending on whether the primers were degenerate and the stringency levels required.

Plasmid template sequencing. Sequencing reactions were executed using the Pharmacia T7 Sequencing Kit as per the manufacturer's instructions, with the following modifications: $2 \mu \mathrm{g}(4 \mu \mathrm{l})$ template plasmid was denatured by the addition of $2 \mathrm{M} \mathrm{NaOH}(1 \mu \mathrm{l})$ and incubated at room temperature for $10 \mathrm{~min}$. The reaction was neutralized by the addition of $3 \mathrm{M}$ sodium acetate, $\mathrm{pH} 4.8(1.5 \mu \mathrm{l})$ and sterile distilled water $(1.5 \mu \mathrm{l})$. Salts were removed by dialysis using $0.025 \mu \mathrm{m}$ pore filters (VSWPO1300; Millipore) against sterile distilled water for 
$30 \mathrm{~min}$. The denatured DNA was made up to $10 \mu \mathrm{l}$ with sterile distilled water and used in an annealing reaction with annealing buffer $(2 \mu \mathrm{l})$ and $8.8 \mathrm{ng}$ sequencing primer $(2 \mu \mathrm{l})$ which was incubated at $37^{\circ} \mathrm{C}$ for $20 \mathrm{~min}$. Labelling proceeded as per the Pharmacia instruction booklet with $\left[{ }^{35} \mathrm{~S}\right] \mathrm{dATP} \alpha \mathrm{S}$ purchased from Amersham.

Polyacrylamide gels $(6 \%, \mathrm{w} / \mathrm{v})$ were used to analyse the sequencing reactions and glass plates were assembled according to the Pharmacia instruction booklet, except that both plates were coated with $5 \%(\mathrm{v} / \mathrm{v})$ Sigmacote (Sigma)/95\% (v/v) chloroform.

Gene sequences and corresponding amino acid sequences were used in homology searches of both DNA (GenBank and EMBL) and protein (Swissprot) databases made available through the Daresbury Seqnet computer system; homology searches were via the FASTA program (Pearson \& Lipman, 1988).

\section{RESULTS AND DISCUSSION}

\section{Growth of $S$. aureus at reduced water activity}

S. aureus RN4220 was evaluated for growth in TSB (Oxoid) and TSB plus $\mathrm{NaCl}(0 \cdot 5-4 \cdot 0 \mathrm{M})$, and from the exponential phase of each culture the specific growth rate $(\mu)$ was calculated. As the $\mathrm{NaCl}$ concentration increased (and thus $a_{\mathrm{w}}$ decreased) the growth rate began to decline from a $\mu_{\max }$ of 0.66 to a $\mu$ of 0.02 at $3.5 \mathrm{M} \mathrm{NaCl}$; the cell yield also decreased. No growth occurred in media containing more than $3.5 \mathrm{M} \mathrm{NaCl}$ even after 30 h. S. aureus RN4220 can therefore tolerate between 3.0 and $3.5 \mathrm{M}$ $\mathrm{NaCl}$ during aerobic growth, corresponding to an $a_{\mathrm{w}}$ of $0.83-0.86$. This is in accordance with previous literature for S. aureus (Scott, 1953; Tatini, 1973).

\section{Protein profiles of osmotically stressed cultures}

SDS-PAGE protein profiles of $S$. aureus cultures were examined after growth in increasing concentrations of $\mathrm{NaCl}$. The production of at least four proteins with molecular masses of about 50 (Protein 1), 40 (Protein 2), 34 (Protein 3) and $25 \mathrm{kDa}$ (Protein 4) were induced at $\mathrm{NaCl}$ concentrations of $2.5 \mathrm{M}\left(a_{\mathrm{w}}\right.$ of 0.88$)$ or above, indicating that $S$. aureus responds to osmotic stress in a manner similar to that observed in the enterics, i.e. hyperosmotic shock causes the induction of a number of proteins. Fig. 1(a) shows a section of a preparative SDSPAGE gel with a control of total protein extract prepared from non-osmotically shocked cells (lane 2) and total protein extracts from cultures grown in the presence of $2.5 \mathrm{M} \mathrm{NaCl}$ (lanes 3 and 4). The technique used to prepare the protein profiles included a concentration step which was achieved by using a Centricon-30 concentrator. This device has a membrane with a molecular mass cut-off of $30 \mathrm{kDa}$; therefore any proteins with a globular structure and molecular mass above $30 \mathrm{kDa}$ will be retained, while those with a molecular mass below $30 \mathrm{kDa}$ will be lost. Proteins with an unusual conformation, e.g. extended filaments, may show anomalous results. Protein 4 has an estimated molecular mass of about $25 \mathrm{kDa}$ but is still retained by the Centricon-30. In its native state, it must therefore either be a dimer or multimer, have an unusually (a)

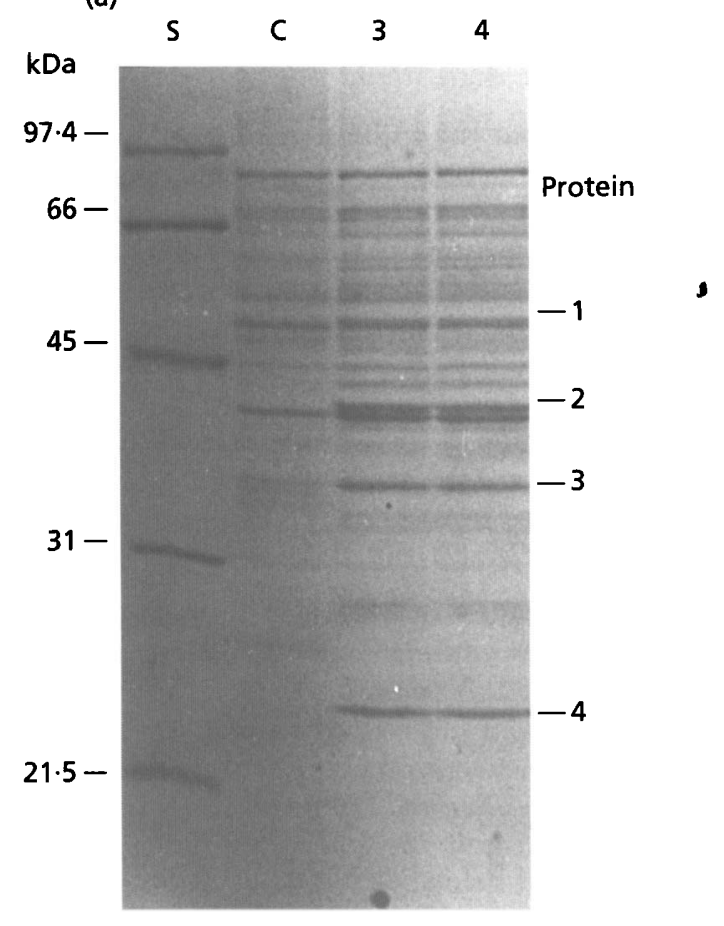

(b)

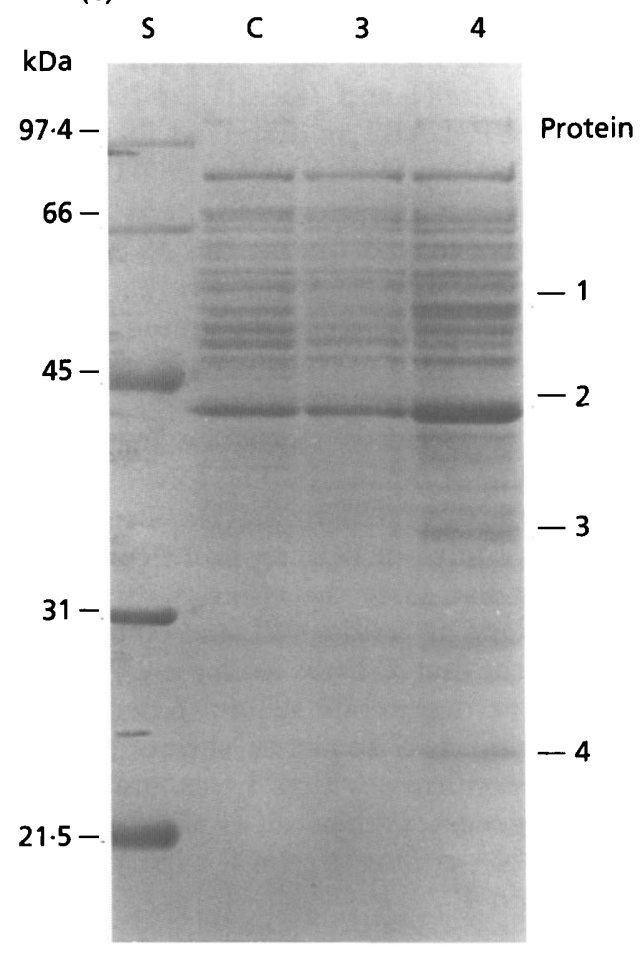

Fig. 1. SDS-PAGE gels of $S$. aureus total cell protein extracts prepared from non-osmotically shocked cells and cultures grown in the presence of (a) $2.5 \mathrm{M} \mathrm{NaCl}$ (lanes 3 and 4) and (b) $0.6 \mathrm{M}$ sucrose (lane 3) and 1.2 M sucrose (lane 4). The production of at least four proteins with molecular masses of about 50 (Protein 1), 40 (Protein 2), 34 (Protein 3) and $25 \mathrm{kDa}$ (Protein 4) are induced (indicated on right-hand side). Lanes S, molecular mass markers; lanes $C$, uninduced culture control. 
extended conformation, or be a subunit of a larger protein structure, since the concentration step is performed before the proteins are denatured.

To establish that the induction of protein 4 is indeed a consequence of an osmotic stress, the response of $S$. aureus to the alternative osmolyte sucrose was determined. Fig. 1 (b) shows the protein profiles of $S$. aureus grown in the pręsence of 0.6 and $1.2 \mathrm{M}$ sucrose cultures as compared to a control culture containing no sucrose. At least four proteins with molecular masses of about 50 (Protein 1), 40 (Protein 2), 34 (Protein 3) and $25 \mathrm{kDa}$ (Protein 4) were induced in response to osmotic stress caused by $1.2 \mathrm{M}$ sucrose. These are the same molecular masses as the four proteins induced in response to osmotic stress caused by the presence of $\mathrm{NaCl}$ (Fig. 1a).

The first 20 residues of Protein 4 were derived following transfer of the protein onto ProBlott membrane by automatic sequencer computer analysis and the confidence level for all the amino acids named in the sequence is $100 \%$, the only exception being the initial glycine residue. The information derived from this sequence analysis was utilized to determine the coding region of the structural gene as detailed below.

\section{Cloning the gene for Protein $\mathbf{4}$ by reverse genetics}

The primer LAB2 incorporates sites for the restriction enzymes SmaI, EcoRI and HindIII, and PCR was performed using UP/LAB2 as described in Methods. The approximately $600 \mathrm{bp}$ PCR product contains two EcoRI sites, one from the multiple cloning site at the $3^{\prime}$ end next to the UP sequence and one at the $5^{\prime}$ end within the sequence of LAB2. The fragment was therefore cut with EcoRI and ligated into the corresponding site in pUC19. This construct was used to transform E. coli JM109 and a recombinant containing the correct size fragment (pLAB2) was subjected to restriction map analysis and DNA sequencing of the insert. The DNA sequence (data not shown) of the $624 \mathrm{bp}$ insert was translated for all three reading frames. Only one reading frame contains an ORF of a significant size since the other two reading frames show stop codons at residues 21 and 6 , respectively. A comparison of the first 33 bases from the ORF in frame ' $a$ ' (ORF1) with the degenerate sequence derived from the $\mathrm{N}$-terminal amino acid sequence showed that they are identical and confirms which bases are used in the positions of degeneracy; thus it is established that pLAB2 contains the DNA coding region for the 190 amino acid $24 \cdot 3 \mathrm{kDa}$ Protein 4.

\section{Protein 4 shows extensive homology to protein sequences from the databases}

A DNA homology search indicated extensive homology between the $S$. aureus sequence from pLAB2 and the $a b p C$ gene from E. coli and Sal. typhimurium extending over the majority of the $624 \mathrm{bp}$ (Tartaglia et al., 1990). Since such a high degree of identity exists at the DNA level, a probe

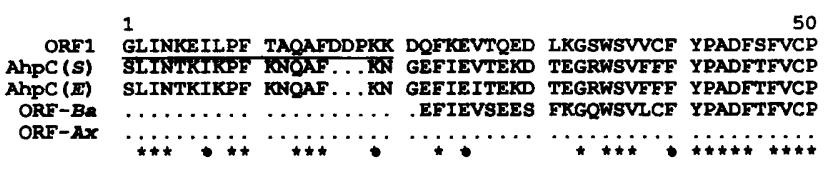

ORF1 ${ }^{51}$ TELEDLONOY EELOKLGUNV FSVSTDTHFV HKAWHDHSDA ISKITYTMIG AhPC (S) TELGDVADHY EELQILGVDV YSVSTDTHFT HKAWHSSSET IAKIKYAMIG AhPC (E) TELGDVADHY EELQRLGVDV YAVSTDTHFT HKANHSSSET IAKIKYAMIG ORF-B. TELEDLONEY AALKELGVEV FSASTDTHFT HKGWHSSET IGKITYAMIG

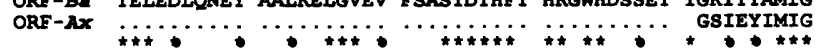
ORF1 101 DPSQTITRNF DVDDEATGLA QRGTEIIDPD GVVOASEINA DGIGRDASTL AhpC (s) DPTGALTRNF DNMREDEGIA DRATrVVDPQ GIIOAIEVTA EGIGRDASDI AhpC (E) DPTGAITRNF DNREDEGIA DRATFVVDPQ GIIOAIEVTA EGIGRDASDL ORF-B. DPSQTLSRNF DVINEVSGLA DRGTFIIDPD GVVOANEINA EGIGRDASTI ORF-AX DPSQTISRQF DVINEETGLA DRGTEIIDPD GVIOAIEINA DGIGRDASTI D* $*$.

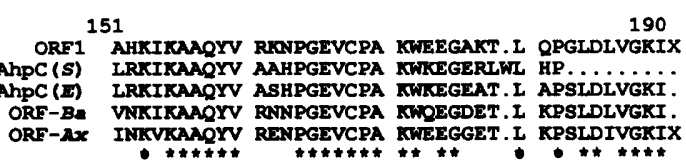

Fig. 2. A matrix of each of the amino acid sequences shown to have significant homology with ORF1 from $S$. aureus was constructed. Identical residues are indicated by an asterisk. Key: $A h p C(S)$, AhpC protein from Sal. typhimurium; AhpC(E), AhpC protein from $E$. coli; ORF-Ba, unidentified ORF from $B$. alcalophilus; ORF-Ax, unidentified ORF from A. xylanus.

designed from any part of the 624 bp PCR fragment will hybridize to the $a b p C$ region of the $E$. coli genome. This was observed experimentally as the PCR probe appeared to hybridize non-specifically against an $E$. coli host used in preparing a $S$. aureus DNA library (data not shown).

\section{Secondary structure plots}

Unidentified ORFs from B. alcalophilus (Xu et al., 1991), Ampbibacillus xylanus (Niimura et al., 1993) and the AhpC proteins from E. coli and Sal. typhimurium (Tartaglia et al., 1990 ) contain over $50 \%$ identity with Protein 4 from $S$. aureus (Fig. 2). In the case of B. alcalophilus, the ORF is located adjacent to the $n d h$ gene which encodes an NADH dehydrogenase (Xu et al., 1991), while in A. xylanus, the ORF is adjacent to the nox gene, which encodes an NADH oxidase (Niimura et al., 1993). Both enzymes perform similar functions in that they can catalyse electron transfer from $\mathrm{NADH}$ to a typical electron acceptor of $\mathrm{NADH}$ dehydrogenase and their amino acid sequences share $72.5 \%$ sequence identity. Thus, it is reasonable to hypothesize that the two unidentified ORFs upstream, but in the same operon as the $n d b$ and nox genes, also share similar functions.

AhpC is encoded by $a b p C$ and this gene is part of an operon in both E. coli and Sal. typhimurium. The gene immediately downstream from $a b p C$ is $a b p F$, encoding $\mathrm{AhpF}$, and $\mathrm{AhpF}$ and $\mathrm{AhpC}$ together function as an alkyl hydroperoxide reductase which protects the enteric bacterium against the toxic by-products of oxidative metabolism. Secondary structure comparisons between AhpC from E. coli, Sal. typhimurium and Protein 4 of $S$. aureus 


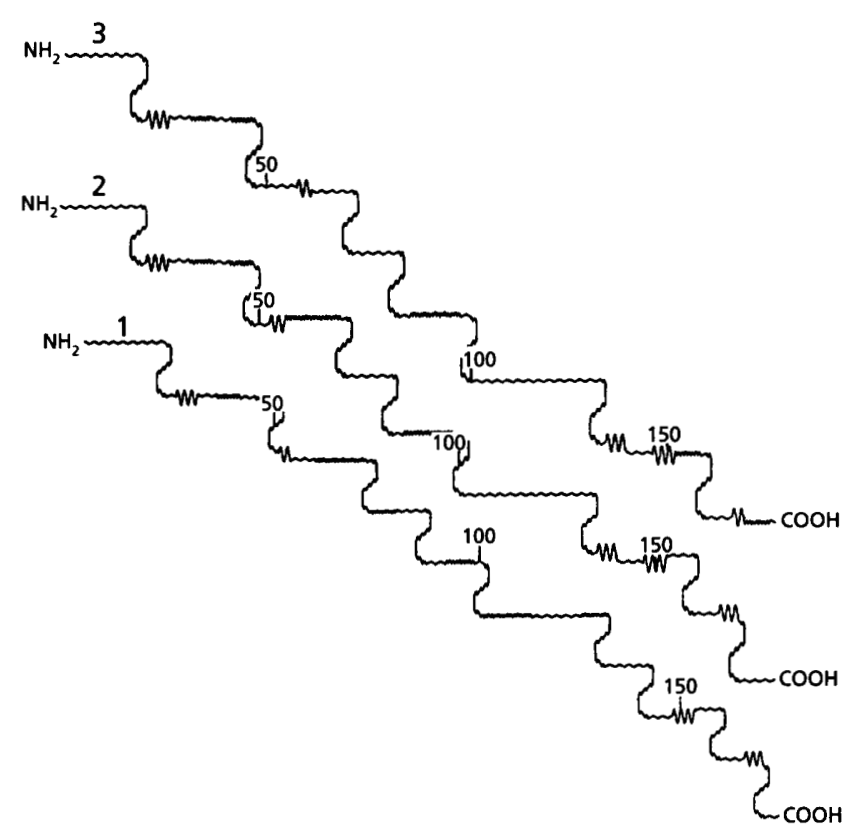

Fig. 3. Chou-Fasman plots for ORF1 from $S$. aureus (1), AhpC from E. coli (2) and AhpC from Sal. typhimurium (3) reiterate the extreme structural homology shared by all three proteins. Key:mww, $\alpha$-helix; $M, \beta$-sheet; $\sim$, coil region; $180^{\circ}$ rotation in direction of polypeptide, $\beta$-turn.

were examined by Chou-Fasman prediction plots (Chou \& Fasman, 1978) using the program PlOtstruCture (Fig. 3). Chou-Fasman prediction plots that appear similar indicate proteins of similar function; these plots indicate the $\alpha$-helical, $\beta$-sheet, coil regions and $\beta$-turns of a protein and provide a visually illustrative comparison of protein homology that extends beyond primary structure since conservative changes in important amino acids are appropriately reflected. The remarkable identity demonstrated to exist between Protein 4 and the AhpC protein from E. coli and Sal. typhimurium at the gene, amino acid and secondary structure levels indicate that Protein 4 (ORF 1) is the AhpC protein from $S$. aureus and that pLAB2 contains the coding region of $a b p C$.

Further support for this assignment comes from the observation that a truncated 84 bp potential ORF, $3^{\prime}$ to $a b p C$, and in the same reading frame as $a b p C$, has $47.8 \%$ identity at the DNA level and $43.5 \%$ identity (over 23 amino acids) at the protein level with $a b p F$ and its encoded protein $\mathrm{AhpF}$, respectively. AhpF is the large subunit $(56 \mathrm{kDa})$ of the $E$. coli alkyl hydroperoxide reductase (Tartaglia et al., 1990) and the $\mathrm{N}$-terminal homology to the ORF increases to $65.2 \%$ when conservative substitutions are considered (data not shown). It appears that $a b p C$ and $a b p F$ are adjacent genes in the $S$. aureus genome, as they are in the enterics (Tartaglia et al., 1990). Interestingly, Protein 1 in Fig. 1(a) has a molecular mass of about $50 \mathrm{kDa}$, is induced in response to osmotic stress in concordance with Protein 4 and could, therefore, represent the $S$. aureus $\mathrm{AhpF}$ protein. Association of the

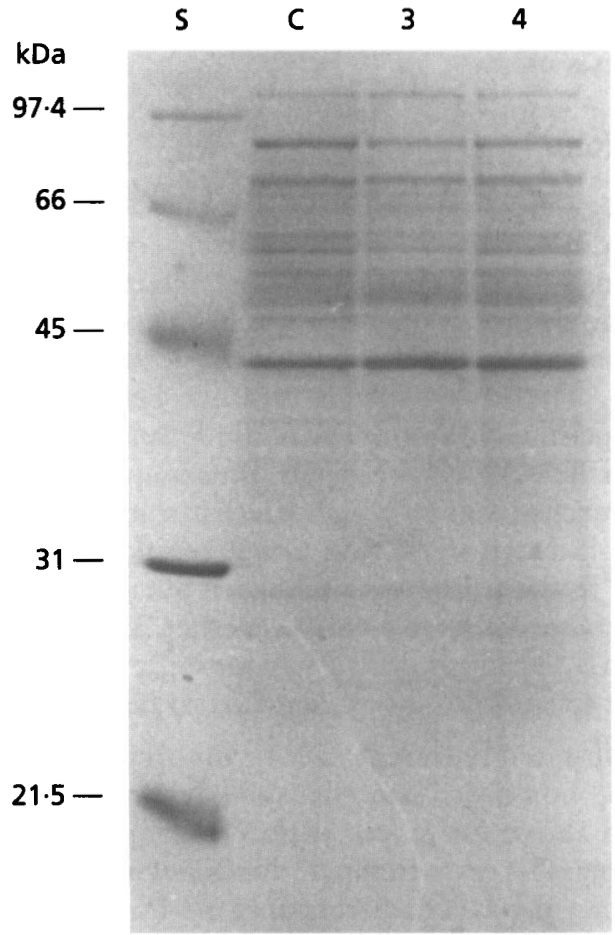

Fig. 4. SDS-PAGE gel of $S$. aureus total cell protein following oxidative stress with $100 \mu \mathrm{M} \mathrm{H} \mathrm{H}_{2}$. Lanes: $\mathrm{S}$, molecular mass markers; $\mathrm{C}$, control (no $\mathrm{H}_{2} \mathrm{O}_{2}$ treatment); 3,10 min posttreatment; 4, 60 min post-treatment.

two alkyl hydroperoxide reductase subunits (namely $\mathrm{AhpC}$ and $\mathrm{AhpF}$ ) would explain the retention of the $25.4 \mathrm{kDa}$ AhpC subunit by the filtration system, which employed a $30 \mathrm{kDa}$ cut-off filter.

In both E. coli and Sal. typhimurium, AhpC is involved in the oxidative stress response; the induction of $a b p C$ in response to oxidative stress in $S$. aureus was therefore investigated.

\section{The induction of $S$. aureus ahpC in response to oxidative stress}

Studies on the effects of oxidative stress in Sal. typhimurium (Morgan et al., 1986) and B. subtilis (Murphy et al., 1987), have indicated that concentrations of $\mathrm{H}_{2} \mathrm{O}_{2}$ used for pretreatment ( 60 and $50 \mu \mathrm{M}$, respectively) induce the production of oxidative stress proteins within $60 \mathrm{~min}$ with no need to subsequently expose cultures to higher concentrations of $\mathrm{H}_{2} \mathrm{O}_{2}$ to visualize these proteins. Thus, to examine the protein content of $S$. aureus under oxidative stress, cultures in mid-exponential phase were subjected to a treatment of $100 \mu \mathrm{M} \mathrm{H}_{2} \mathrm{O}_{2}$ for 10 and $60 \mathrm{~min}$ and total cell protein was subsequently prepared and run on an SDS-PAGE gel. Fig. 4 indicates that, using the same protein analysis system (one-dimensional Coomassieblue-stained gel), no obvious induction of protein occurs within 60 min of exposure to $\mathrm{H}_{2} \mathrm{O}_{2}$. Lower levels of 
induction may occur which cannot be deduced from the gel analysis used.

\section{Conclusions}

OxyR regulates the induction of $\mathrm{AhpC}$ in response to $\mathrm{H}_{2} \mathrm{O}_{2}$-induced stress in the enteric bacteria due to oxidation-induced conformational changes in $\mathrm{OxyR}$ already bound to an operator site in the promoter region (Christman et al., 1989; Tao et al., 1989; Storz et al., 1990a,b). The OxyR system has not been identified as being functional in stationary phase $E$. coli cultures which are nevertheless $\mathrm{H}_{2} \mathrm{O}_{2}$-resistant, thus it appears that there are two mechanisms by which $E$. coli can adapt to exposure to $\mathrm{H}_{2} \mathrm{O}_{2}$-induced stress, the OxyR regulon and the rpoS $\left(k a t F ; \sigma^{\mathrm{s}}\right)$ system; there is no known overlap between the two (Hengge-Aronis, 1993). Whether a similar system occurs in $S$. aureus, and if so whether it is involved in the response to osmotic shock, remains to be elucidated.

A growth-rate-dependent theory involving an rpoS-like factor is, however, one plausible hypothesis since, as indicated above for E. coli, RpoS (Hengge-Aronis et al., 1993 ) integrates growth rate induction with the induction of proteins produced in response to both osmotic and $\mathrm{H}_{2} \mathrm{O}_{2}$ stress. If in $S$. aureus, changes in growth rate underlie the osmotic induction of $a b p C$, a hypothesis can be developed which suggests that cultures subjected to a growth-rate-reducing form of stress (e.g. osmotic stress), and which are not also undergoing nutrient starvation, will still metabolize nutrients at the normal rate. Since the growth rate has decreased, the cell is effectively overmetabolizing; the cell senses this over-metabolism in some way and responds by inducing the production of a number of proteins which are globally termed stress proteins. Some of these proteins will help to alleviate the particular form of stress being encountered; in essence a fail safe or 'safety net' response. We are currently constructing a strain of $S$. aureus defective in $a b p C$ to establish to what extent $\mathrm{AhpC}$ is essential to global stress adaptation in this Gram-positive bacterium.

\section{ACKNOWLEDGEMENTS}

We would like to thank Professor Ian Booth (University of Aberdeen) for helpful discussion and for introducing us to the 'safety net' hypothesis. L. Armstrong-Buisseret was supported on an AFRC CASE studentship ref. F046CS.

\section{REFERENCES}

Ausubel, F. M., Brent, R., Kingston, R. E., Moore, D. D., Seidman, J. G., Smith, J. A. \& Struhl, K. (1990). In Current Protocols in Molecular Biology, Vol. 2. Chichester: John Wiley and Sons.

Bae, J.-H. \& Miller, K. J. (1992). Identification of two proline transport systems in Staphylococcus aureus and their possible roles in osmoregulation. Appl Environ Microbiol 58, 471-475.

Bae, J.-H., Anderson, S. H. \& Miller, K. J. (1993). Identification of a high affinity glycine betaine transport system in Stapbylococcus aureus. Appl Environ Microbiol 59, 2734-2736.

Bergdoll, M. S. (1983). Enterotoxins. In Staphylococci and Staphylococcal Infections, pp. 559-598. Edited by C. S. F. Eastman \& C. Adlam. London: Academic Press.
Chou, P. Y. \& Fasman, G. D. (1978). Prediction of the secondary structure of proteins from their amino acid sequences. Adv Enzymol 147, 45-148.

Christman, M. F., Storz, G. \& Ames, B. N. (1989). OxyR, a positive regulator of hydrogen peroxide-inducible genes in Escherichia coli and Salmonella typhimurium is homologous to a family of bacterial regulatory proteins. Proc Natl Acad Sci US A 86, 3484-3488.

Graham, J. E. \& Wilkinson, B. J. (1992). Stapbylococcus aureus osmoregulation: roles for choline, glycine betaine, proline and taurine. J Bacteriol 174, 2711-2716.

Hengge-Aronis, R. (1993). The role of rpoS in early stationaryphase gene regulation in Escherichia coli K12. In Starvation in Bacteria, pp. 171-200. Edited by S. Kjelleberg. New York: Plenum Press.

Hengge-Aronis, R., Large, R., Henneberg, N. \& Fischer, D. (1993). Osmotic induction of rpoS-dependent genes in Escherichia coli. $J$ Bacteriol 175, 259-265.

Iwanejko, L. A., Routledge, M. N. \& Stewart, G. S. A. B. (1989). Cloning in Escherichia coli of the enterotoxin gene from Clostridium perfringens Type A. J Gen Microbiol 135, 903-909.

Jay, J. M. (1992). Modern Food Microbiology, 4th edn, pp. 455-478. New York: Van Nostrand Reinhold.

Johnson, W. M., Tyler, S. D., Ewan, E. P., Ashton, F. E., Pollard, D. R. \& Rozee, K. R. (1991). Detection of genes for enterotoxins, exfoliative toxins and toxic shock syndrome Toxin I in Stapbylococcus aureus by PCR. J Clin Microbiol 29, 426-430.

Johnstone, K., Simom, F. A. \& Ellar, D. J. (1982). Teichoic acid and lipid metabolism during sporulation of Bacillus megaterium KM. Biocbem J 202, 459-467.

Kaenjak, A., Graham, J. E. \& Wilkinson, B. J. (1993). Choline transport activity in Stapbylococcus aureus induced by osmotic stress and low phosphate concentration. J Bacteriol 175, 2400-2406.

Kreiswirth, B. N., Lăfdahl, S., Bistley, M. J., O'Reiley, M., Schlievert, P. M., Bergdoll, M. S. \& Novick, R. P. (1983). The toxic shock syndrome exotoxin structural gene is not detectably transmitted by a prophage. Nature 303, 709-712.

Kunin, C. M. \& Rudy, J. (1991). Effect of sodium chloride-induced osmotic stress on intracellular concentrations of glycine betaine and potassium in Eschericbia coli, Enterococcus faecalis and Staphylococci. $J$ Lab Clin Med 118, 217-224.

Miller, K. J., Zelt, S. C. \& Bae, J.-H. (1991). Glycine betaine and proline are the principal compatible solutes of Staphylococcus aureus. Curr Microbiol 23, 131-137.

Morgan, R. W., Christman, M. F., Jacobson, F. S., Storz, G. \& Ames, B. N. (1986). Hydrogen peroxide-inducible proteins in Salmonella typhimurium: overlap with heat-shock and other stress proteins. Proc Natl Acad Sci US A 83, 8059-8063.

Murphy, P., Dowds, B. C., McConnell, D. J. \& Devine, K. M. (1987). Oxidative stress and growth temperature in Bacillus subtilis. J Bacteriol 169, 5766-5770.

Niimura, Y., Ohnishi, K., Yarito, Y., Hidaka, M., Masaki, H., Uchimura, T., Suzuki, H., Kozaki, M. \& Uozumi, T. (1993). A flavoprotein functional as NADH oxidase from Amphibacillus xylanus Ep01: purification and characterization of the enzyme and structural analysis of its gene. J Bacteriol 175, 7945-7950.

Noble, W. C. \& White, M. I. (1983). Staphylococcal skin infections in man. In Stapbylococci and Staphylococcal Infections, pp. 165-191. Edited by C. S. F. Eastman \& C. Adlam. London: Academic Press.

Parker, M. T. (1984). Staphylococcal diseases. In Topley and Wilson's Principles of Bacteriology, Virology and Immunity, Vol. 3, pp. 254-278. Edited by G. R. Smith. London: Edward Arnold. 
Pearson, W. R. \& Lipman, D. J. (1988). Improved tools for biological sequence comparison. Proc Natl Acad Sci USA 85, 2444-2448.

Pourkomailian, B. \& Booth, I. R. (1993). Glycine betaine transport by Stapbylococcus aureus: evidence for two transport systems and for their possible roles in osmoregulation. $J$ Gen Microbiol 138, 2515-2518.

Saiki, R. K., Gelford, D. H., Stoffel, S., Scharf, S. J., Higudin, R., Horn, G. T., Mullis, K. B. \& Erlich, H. A. (1988). Primer-directed enzymatic amplification of DNA with a thermostable DNA polymerase. Science 239, 487-491.

Sambrook, J., Fritsch, E. F. \& Maniatis, T. (1989). Molecular Cloning: A Laboratory Manual, 2nd edn. Cold Spring Harbor, NY: Cold Spring Harbor Laboratory.

Scott, W. J. (1953). Water relations of Staphylococcus aureus at $30^{\circ} \mathrm{C}$. Aust J Biol Sci 6, 549-564.

Storz, G., Tartaglia, L. A. \& Ames, B. N. (1990a). Transcriptional regulation of oxidative stress-inducible genes: direct activation by oxidation. Science 248, 189-194.

Storz, G., Tartaglia, L. A., Farr, S. B. \& Ames, B. N. (1990b). Bacterial defences against oxidative stress. Trends Genet 6, 363-368.

Tao, K., Makino, K., Yonei, S., Nakata, A. \& Shinagawa, H. (1989). Molecular cloning and nucleotide sequencing of $\operatorname{exy} R$, the positive regulatory gene of a regulon for an adaptive response to oxidative stress in Escherichia coli: homologies between OxyR protein and a family of bacterial activator proteins. Mol \& Gen Genet 218, $371-376$.
Tartaglia, L. A., Storz, G., Brodsky, M. H., Lait, A. \& Ames, B. N. (1990). Alkyl hydroperoxide reductase from Salmonella typhimurium. $J$ Biol Cbem 265, 10535-10540.

Tatini, S. R. (1973). Influence of food environments on growth of Staphylococcus aureus and production of various enterotoxins. $J$ Milk Food Technol 36, 559-563.

Townsend, D. E. \& Wilkinson, B. J. (1992). Proline transport in Stapbylococcus aureus: a high affinity system involved and a low affinity system involved in osmoregulation. $J$ Bacteriol 174, $2702-2710$

Troller, J. A. (1986). Water relations of foodborne bacterial pathogens: an updated review. J Food Prot 49, 656-670.

Wheat, L. J., Kohler, R. B. \& White, A. (1983). Diagnosis and management of deep seated infection. In Staphylococci and Staphylococcal Infections, pp. 121-148. Edited by C. S. F. Eastman \& C. Adlam. London: Academic Press.

Xu, X., Koyamam, N., Cui, M., Yamagishi, A., Nosoh, Y. \& Oshima, T. (1991). Nucleotide sequence of the gene encoding $\mathrm{NADH}$ dehydrogenase from an alkalophile Bacillus species, strain YN-1. $J$ Biochem 109, 678-683.

Yanisch-Perron, C., Vieira, J. \& Messing, J. (1985). Improved M13 phage cloning vectors and host strains: nucleotide sequences of the M13mp18 and pUC19 vectors. Gene 33, 103-119.

Received 12 December 1994; revised 3 March 1995; accepted 27 March 1995. 